\title{
DOCKING MOLEKUL DENGAN METODA MOLEGRO VIRTUAL DOCKER DARI EKSTRAK AIR Psidium guajava, Linn DAN Citrus sinensis, Peels SEBAGAI INHIBITOR PADA TIROSINASE UNTUK PEMUTIH KULIT
}

\author{
MOLECULAR DOCKING USING MOLEGRO VIRTUAL DOCKER (MVD) ON WATER EXTRACT \\ OF GUAVA FRUIT (PSIDIUM GUAJAVA, LINN) AND SWEET ORANGE (citrus sinensis, peels) AS \\ INHIBITOR ON ENZYME TYROSINASE AS POSITIVE CONTROL OF WHITENING AGENT
}

\author{
Ayik Rosita Puspaningtyas \\ Fakultas Farmasi, Universitas Jember, Jember \\ Jl. Kalimantan I No.2, Kampus Tegal Boto Jember 68121 \\ Email : aixrose_pee@yahoo.co.id
}

Diterima : 8 Maret 2013, Direvisi : 19 Maret 2013, Disetujui : 25 Maret 2013

\begin{abstract}
ABSTRAK
Kami telah melakukan docking molekul dengan menggunakan Molegro Virtual Docker pada ekstrak air buah jambu biji (Psidiumguajava, Linn) dan jeruk manis (Citrus sinensis, Peels) sebagai inhibitor pada enzim tirosinase dengan control positif vitamin $\mathrm{C}$ dalam upaya mencari whitening agent. Berdasarkan hasil penelitian sebelumnya didapatkan senyawa kandungan utama ekstrak air buah jambu biji (Psidium guajava, Linn) adalah 2,6-dihidroksi-3,5dimetil-4-O- $\beta$-D-glukopiranosil benzofenon, 3-hidroksi-2butanon, dan vitamin $\mathrm{C}$ sedangkan ekstrak air buah jeruk manis (Citrus sinensis) adalah limonen, linalol, dan vitamin C. Pada penelitian ini didapatkan hasil docking senyawa pada kandungan utama ekstrak air buah Psidium guajava memiliki ikatan yang lebih baik sebagai inhibitor enzim tirosinase daripada Citrus sinensis dan vitamin C, yang dapat dilihat dari Moldock score yaitu -107,806 sedangkan pada Citrus sinensis $-76,9593$, yang artinya senyawa pada ekstrak air Psidium guajava memiliki energi yang lebih rendah sehingga lebih stabil dalam pengikatannya terhadap reseptor daripada senyawa ekstrak air Citrus sinensis. Hasil serupa ditunjukkan dari uji in vitro pada ekstrak air buah jambu biji (Psidiumguajava) dengan $\mathrm{IC}_{50} 0,26 \mathrm{mM}$ sedangkan ekstrak air jeruk manis (Citrus sinensis) $\mathrm{IC}_{50} 31,07 \mathrm{mM}$. Hal ini juga didukung oleh data ikatan hydrogen kandungan utama ekstrak air buah jambu biji (Psidium guajava) 2,6-dihidroksi3,5-dimetil-4-O- $\beta$-D-glukopiranosil benzofenon dengan 5 asam amino tirosinase antara lain Gly 200, Pro 201, Gly 196, Phe 197, dan Asn205 sedangkan pada limonene, linalool mengikat 3 asam amino yaitu Gly 200, Phe 197,dan Asn205. Dengan demikian dapat disimpulkan bahwa interaksi ekstrak air buah jambu biji (Psidiumguajava) terhadap enzim tirosinase lebih harmonis dan stabil daripada vitamin $\mathrm{C}$ maupuns enyawa pada ekstrak air jeruk manis (Citrus sinensis).
\end{abstract}

Kata kunci : Psidium guajava, Citrus sinensis, tirosinase, vitamin C dan docking Molekul.

\section{ABSTRACT}

We have been molecular docking using Molegro Virtual Docker (MVD) on water extract of guava fruit (Psidiumguajava, Linn) and sweet orange (Citrus sinensis,Peels) as inhibitor on enzyme tyrosinase with ascorbic acid (vitamin C) as positive control to study whitening agent. Based on the previous studies, the main content of the water extract of guava fruit (Psidiumguajava) are 2,6-dihydroxy-3,5-dimethyl-4-O--D-glucopyranosil benzophenone, 3-hydroxy-2-butanone, and vitamin $C$, while the extract juice of sweet oranges (Citrus sinensis) are limonene, linalol, and vitamin $C$. In this study the results showed that the main content of the water extract of Psidium guajava fruit have better bond as inhibitor on tyrosinase than Citrus sinensis and vitamin $C$ which can be seen from Moldock score of Psidiumguajava (-107.806) and Citrus sinensis $(-76,9593)$; it meanslower the energyand more stable binding. The $I C_{50}$ on water extract of guava fruit (Psidiumguajava) and sweet orange (Citrus sinensis) were $0.26 \mathrm{mM}$ and $31.07 \mathrm{mM}$, respectively. The hydrogen bonds of 2,6-dihydroxy-3,5-dimethyl-4-O--D-glucopyranosil benzophenone with 5 amino acid of tyrosinase were Gly 200, Pro 201, Gly 196, Phe 197, and Asn 205, while limonen, linalool binding 3 amino acids were Gly 200, Phe 197, and Asn 205. Finally, 3D MVD visualization between main content of guava and sweet orange water extract can be concluded that interaction of guava fruit (Psidiumguajava) water extract against tyrosinase was more harmonious and stabil than vitamin $C$ and main content of sweet orange (Citrus sinensis) water extract.

Keywords: Psidium guajava, Citrus sinensis, tyrosinase, vitamin C and docking molecule

\section{PENDAHULUAN}

Indonesia merupakan negara tropis yang kaya akan sinar matahari sepanjang tahun. Sinar matahari 
memiliki peran penting bagi kehidupan seluruh makhluk hidup di bumi. Bagi manusia, sinar matahari berguna untuk mengubah pro vitamin $\mathrm{D}_{3}$ (7dehidrokolesterol) di epidermis kulit menjadi vitamin D pada pembentukan tulang ${ }^{(5,22,23,27)}$. Namun di sisi lain, paparan sinar matahari yang berlebihan juga dapat menimbulkan efek yang tidak diinginkan bagi kulit manusia seperti terjadinya penuaaan dini, kanker kulit dan hiperpigmentasi ${ }^{(23,29,33)}$.

Hiperpigmentasi merupakan suatu gangguan pigmentasi kulit berupa peningkatan produksi melanin yang mengakibatkan pigmentasi lokal atau spot di kulit. Gambaran hiperpigmentasi adalah warna kulit yang lebih gelap daripada keadaan normal ${ }^{(23,33)}$. Pembentukan melanin pada prinsipnya merupakan suatu upaya perlindungan kulit dari efek buruk radiasi ultraviolet sinar matahari dan menentukan warna kulit. Namun, kadar melanin yang berlebihan (hiperpigmentasi) sering menimbulkan permasalahan estetika sehingga cara mengatasi hiperpigmentasi dapat dilakukan dengan beberapa cara diantaranya dengan menggunakan bahan pemutih kulit.

Saat ini, banyak beredar produk pemutih kulit di pasaran dengan berbagai bahan aktif dan mekanisme kerja yang beragam. Prinsip utama mekanisme kerja bahan pemutih kulit adalah menghambat pembentukan melanin atau melanogenesis sehingga kulit menjadi lebih cerah dan tampak lebih putih. Pembentukan melanin dapat dihambat dengan berbagai cara salah satunya yaitu dengan menghambat aktivitas tirosinase. Bahan pemutih kulit yang dapat menghambat aktivitas tirosinase diantaranya asam kojat, hidrokuinon, arbutin, aloesin, vitamin C, asam sinamat, dan asam salisilat ${ }^{(27)}$.

Dari beberapa penelitian tentang kosmetik menunjukkan bahwa sebagian dari bahan pemutih kulit dalam produk pemutih kulit tidak' aman dan banyak menimbulkan efek samping bagi kulit. Pemakaian hidrokuinon, asam azelaik, asam kojat, dan Alpha Hydroxy Acids (AHAs) yang umum digunakan dalam produk pemutih kulit pada jangka panjang serta dengan dosis besar dapat mengakibatkan iritasi, rasa terbakar, dermatitis kontak atau peradangan alergi akut, kerusakan kulit, bahkan kanker kulit ${ }^{(3,33)}$. Oleh sebab itu, perlu dilakukan pengembangan senyawa pemutih kulit yang aman, diantaranya dengan menggunakan pemutih kulit dari alam. Berdasarkan penelitian sebelumnya dikatakan bahwa kandungan utama ekstrak air buah jambu biji (Psidium guajava) adalah 2,6-dihidroksi3,5-dimetil-4-O- $\beta$-D-glukopiranosilbenzofenon, 3hidroksi-2-butanon, dan vitamin $\mathrm{C}$ sedangkan ekstrak air buah jeruk manis (Citrus sinensis) adalah limonen, linalol, dan vitamin $C^{(2,6,7,8,10-13,15,16,20,21,28,32,35)}$.

Tirosinase (1.14.18.1) merupakan enzim utama dalam melanogenesis yang terdapat dalam melanosit atau sel pigmen. Fungsi tirosinase adalah mengkatalisis reaksi dalam biosintesis melanin dari tirosin dalam melanosit ${ }^{(9,17,14,18)}$.
Pengembangan obat dalam penemuan inhibitor tirosinase terus meningkat. Salah satunya adalah penelitian tentang kandungan senyawa pada ekstrak air buah jambu biji (Psidium guajava) dan jeruk manis (Citrus sinensis). Gambaran yang unik pada enzim tirosinase adalah selektivitas dalam penghambatannya karena enzim mempunyai active site dan kofaktornya yang berupa logam $\mathrm{Cu}^{2+}$. Hal ini dapat menjadi target rancangan obat rasional dan efektif untuk mencari inhibitor tirosinase sebagai pemutih kulit dalam kosmetik. Saat ini, pendekatan docking molekul telah banyak digunakan dalam rancangan obat modern untuk membantu memahami interaksi ligan-reseptor. Beberapa literatur menunjukkan bahwa teknik komputasi dapat mendukung dan membantu desain senyawa untuk mendapatkan inhibitor yang lebih ampuh melalui mekanisme interaksi ligan-reseptor. Namun, sejauh ini, belum ada laporan tentang penerapan metodologi docking molekuler untuk memahami interaksi pengikatan kandungan senyawa ekstrak air buah jambu biji (Psidium guajava) dan jeruk manis (Citrus sinensis) $)^{(19,24,25,30,31)}$.<smiles>Cc1cc(C)c(O)c(C(=O)c2ccccc2C2O[C@H](CO)[C@@H](O)[C@H](O)[C@H]2O)c1O</smiles>

(a)<smiles>CC(=O)C(C)O</smiles>

(b)

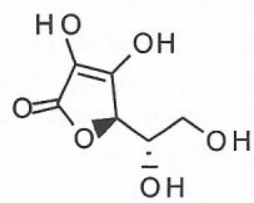

(c)

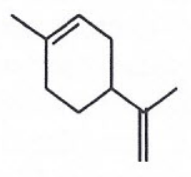

(d)

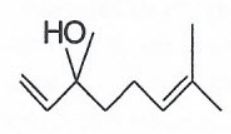

(e)
Gambar 1. Struktur kimia (a) 2,6-dihidroksi-3,5-dimetil-4-Obeta-D-glukopiranosilbenzofenon, (b) 3-hidroksi2-butanon, (c) vitamin C, (d) limonen, (e) linalool ${ }^{(2,6-8,10,11-13,15,16,20,21,28,32,35)}$.

Molekular docking adalah alat utama dalam biologi molekular struktural dengan bantuan komputer untuk desain suatu obat/ligan. Tujuan dari docking protein dan ligan yaitu untuk memprediksi model yang mengikat ligan dengan protein pada struktur tigadimensi. Dalam penelitian ini digunakan docking secara cepat dan fleksibel kandungan senyawa pada ekstrak air buah jambu biji (Psidium guajava) dan jeruk manis (Citrus sinensis) dengan menggunakan Molegro Virtual Docker 2008. Penelitian ini dilakukan untuk memahami bentuk-bentuk interaksi dari kandungan senyawa pada ekstrak air buah jambu biji (Psidium guajava) dan jeruk manis (Citrus sinensis) terhadap enzim tirosinase dibandingkan dengan senyawa vitamin $\mathrm{C}$ yang sudah 
terbukti sebagai pemutih kulit. Vitamin C digunakan sebagai pembanding karena kedua ekstrak tersebut mengandung vitamin $C^{(7,8)}$.

\section{BAHAN DAN METODA}

\section{Perangkat keras dan perangkat lunak}

Molegro Virtual Docker 2008 [http:// www.molegro.com] dan [Sybil2] adalah digunakan untuk pemodelan molekuler pada workstation dengan prosesor dual core.

\section{Struktur Molekul dan Optimasi}

Struktur senyawa kandungan utama ekstrak air buah jambu biji (Psidium guajava) yaitu 2,6-dihidroksi3,5-dimetil-4-O- $\beta$-D-glukopiranosilbenzofenon, dan 3hidroksi-2-butanon. Sedangkan ekstrak air buah jeruk manis (Citrus sinensis) kandungan senyawa utamanya yaitu limonene dan linalool. Senyawa-senyawa dari kandungan kedua ekstrak tersebut digambar dengan menggunakan ChemBio Draw Ultra 11.02008 versi trial (http://www.chemoffice.com) yang dilanjutkan dengan bentuk 3Dnya. Struktur isomer geometri senyawa kandungan utama ekstrak air buah jambu biji (Psidium guajava) yaitu 2,6-dihidroksi-3,5-dimetil-4O- $\beta$-D-glukopiranosilbenzofenon, dan 3-hidroksi-2butanon, sedangkan ekstrak air buah jeruk manis (Citrus sinensis) yaitu limonene dan linalool selanjutnya dioptimalkan dengan menggunakan Tools MM2 pada ChemBio 3D Ultra 11.0 versi trial 2008. Struktur protein pada enzim tirosinase (PDB kode 3NQ1) diperoleh dari Bank Data Protein (http://www.rcsb.org) $)^{(19,24,25,30,31)}$.

\section{Molecular docking}

Docking molekul senyawa kandungan utama ekstrak air buah jambu biji (Psidium guajava) dan jeruk manis (Citrus sinensis) ke tempat sisi aktif enzim tirosinase dilakukan dengan menggunakan docking modern Molegro Virtual Docker 5.0.0 dan disimpan dalam bentuk Sybil2. (http://www.molegro.com). Tahapan tersebut untuk mencari sebuah rongga (cavity) dengan deteksi algoritma untuk mendeteksi tempat ikatan protein sebagai potensi daerah pada sisi aktif untuk berikatan dengan obat (ligan). Penyaringan bentuk ligan yang paling stabil dikombinasikan dengan MM2 sehingga menghasilkan konformasi ligan pose yang konsisten dengan bentuk sisi aktif dari protein/reseptor (enzim tirosinase). Calon pose yang diminimalkan energinya dalam sisi aktif menggunakan metode berbasis grid untuk mengevaluasi interaksi energi protein-ligan yang disimpan dalam Mol2.
Docking dilakukan dengan pengaturan standar non Ligand pada Molegro Virtual Docker dengan 5 cavity namun yang digunakan cavity 3 (volume 40,448) untuk protein enzim tirosinase dengan grid resolusi 0.30 dengan parameter iterasi maksimal 1500 dan ukuran populasi maksimal 50 serta dengan pose generation dengan energi 100.00 . Selain itu evolusi simpleks yang digunakan pada max step 300 dan distance faktor $1.00^{(19,}$ $24,25,30,31)$

\section{Fungsi Penilaian (Skor)}

Bentuk konformasi yang telah didocking lebih lanjut dicetak menggunakan penilaian yang berbeda fungsi yang tersedia dalam [Sybil2].Algoritma Molegro Virtual Docker menggunakan fungsi penilaian internal dimana DockScore digunakan untuk memilih dan kembali membedakan posisi untuk setiap senyawa. DockScore adalah bidang gaya sederhana berdasarkan penilaian fungsi yang memperkirakan energi dari interaksi energi summing ligan/protein dan energi internal dari ligan. Medan gaya pada Molegro Virtual Docker digunakan untuk menyelesaikan parameter elektrostatik untuk DockScore. Posisi putatif 3D menghasilkan skor yang disimpan dalam file Sybil2. Setiap docking yang diminimalkan, murni menggunakan DockScore, mekanika molekul dari fungsi penilaian yang digunakan dalam penelitian ini dan pose ini kemudian disajikan untuk masing-masing fungsi penilaian lainnya seperti Rerank Score, RMSD(Root Mean Standard Deviation) dan H Bond. Gambar 1 menunjukkan bentuk 3D yang disimpan dalam Sybil2. Score yang didapatkan dilakukan replikasi masing-masing 10 kali $^{(19,24,25,30,31)}$.

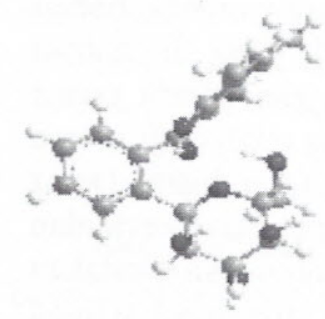

(a)

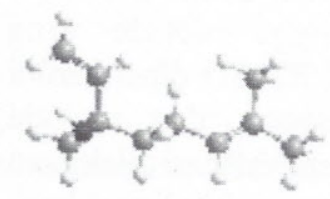

(d)

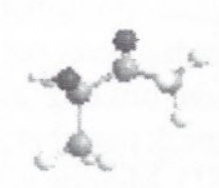

(b)

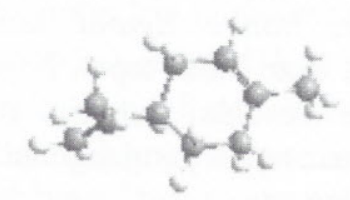

(e)

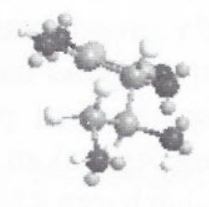

(c)
Gambar 2. Bentuk 3D senyawa kandungan ekstrak air buah jambu biji (Psidium guajava) (a) 2,6-dihidroksi3,5 - dimetil-4-O- $\beta$-D glukopiranosilbenzofenon (b) 3-hidroksi-2-butanon dan senyawa kandungan ekstrak jeruk manis (Citrus sinensis) yang disimpan dalam Sybil2, (d) limonen, (e) linalool serta senyawa pembanding Vitamin C (c). Kesemua struktur senyawa disimpan dalam Sybil2. 


\section{Protein}

Struktur enzim tirosinase yang digunakan adalah (PDB kode 3NQ1) kompleks dengan klasifikasi oxydoreductase yang beresolusi-tinggi $\left(2,30 \mathrm{~A}^{\circ}\right)$ sinar $\mathrm{X}$ dimana terkompleks dengan ligan Kojic Acid yang kemudian diimpor ke Sybil2 ligan diekstraksi untuk meninggalkan suatu rongga untuk diujikan dengan ligan yang lain. Simulasi ikatan dilakukan dengan substrat Kojic Acid dan tanpa molekul air untuk menjelaskan peran hambatan ligan terhadap tirosinase dalam pengikatan senyawa-senyawa kandungan utama ekstrak air buah jambu biji (Psidium guajava) yaitu 2,6dihidroksi-3,5-dimetil-4-O- $\beta$-D-glukopiranosilbenzofenon, dan 3-hidroksi-2-butanon, sedangkan ekstrak air buah jeruk manis (Citrus sinensis) yaitu limonene dan linalool ${ }^{(19,24,25,30,31)}$.

\section{HASIL DAN PEMBAHASAN}

Struktur reseptor yang digunakan dalam penelitian ini adalah kristal enzim tirosinase dengan klasifikasi oxydoreductase yang terkompleks dengan inhibitor Kojic Acid untuk memberikan informasi tentang active site dan komposisi ruang ikatan inhibitor serta kesempatan untuk menggunakan enzim/protein dalam konformasi fungsional. Dalam penelitian ini kami menggunakan struktur sinar $\mathrm{X}$ oxydoreductase dalam kompleks terner dengan substrat Kojic Acid (PDB kode 3NQ1) untuk uji docking.

Validasi metode docking.

Tahap validasi dilakukan untuk mengkalibrasi metode docking pada piranti lunak yang digunakan pada proses validasi ini dibandingkan antara posisi native ligand terhadap reseptor yang telah diuji secara eksperimental pada binding site pocket ligan. Dasar yang digunakan untuk memberikan penilaian kevalidan adalah harga RMSD. Metode yang digunakan dikatakan valid jika harga RMSD kurang dari 2 artinya posisi ligan copy setelah superimpose semakin dekat posisinya menduduki native ligand sehingga metode yang digunakan akan lebih tepat. Nilai RMSD dipengaruhi juga oleh resolusi protein reseptor dan metode pemodelan reseptor yang digunakan. Validasi dilakukan pada binding site pocket ligand dengan 10 kali replikasi. Untuk memastikan bahwa orientasi ligan, perilaku dalam model pengikatan ligan-reseptor dan posisi yang diperoleh dari studi docking dengan menggunakan program Molegro Virtual Docker maka parameter metode docking ini harus terlebih dahulu divalidasi struktur reseptor yang digunakan yaitu PDB kode 3NQ1 dengan jumlah atom 2321 dimana dilakukan replikasi masing-masing 10 kali. Ligan KOJ 1351 (A) adalah kode untuk native ligan dengan enzim tirosinase kemudian native ligan diekstraksi dan dimasukkan ligan baru (senyawa-senyawa ekstrak air Psidium guajava dan Citrus sinensis) ke tempat sisi aktif yang sesuai dalam pengikatan untuk menentukan kemampuan ligan baru dalam mereproduksi orientasi dan posisi inhibitor pada struktur kristal reseptor di dalam cavity. Hasil kontrol docking menunjukkan bahwa dengan program Molegro Virtual Docker orientasi optimal inhibitor yang ditentukan pada native ligan yang terkompleks dengan active site reseptor yaitu KOJ 1351 (A) yang terdiri 10 atom (Gambar 3) letak pada cavity 3 (volume 40,448) yang berwarna hijau dan protein A (3NQ1) pada enzim tirosinase.

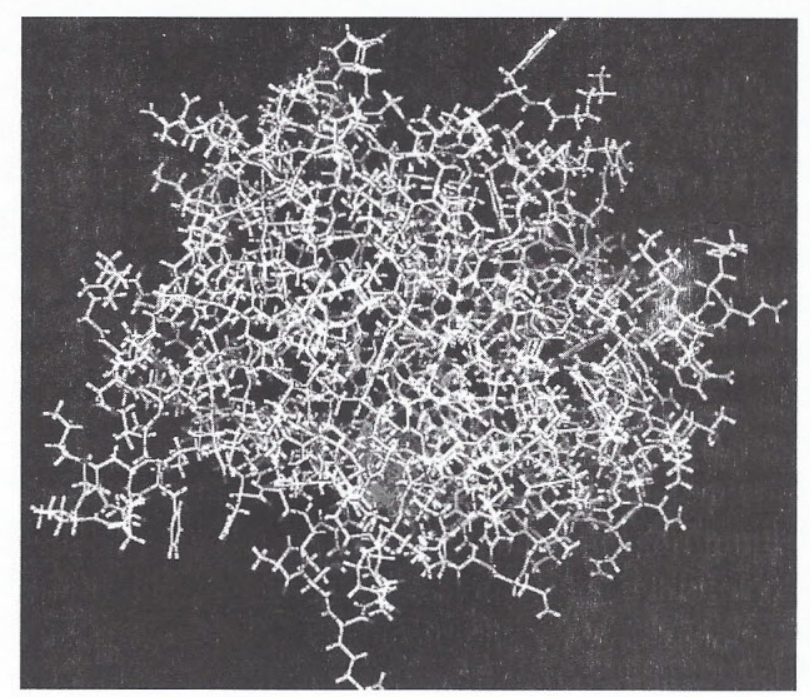

Gambar 3. Struktur kristal enzim tirosinase yang berikatan dengan kompleks ligannya pada cavity 3 (warna hijau)

Interaksi model antara kandungan utama ekstrak air buah jambu biji (Psidium guajava) yaitu 2,6d i h id roks i - 3, 5 - d i m e ti l - 4 - O - b e t a - D glukopiranosilbenzofenon, dan 3-hidroksi-2butanon, sedangkan ekstrak air buah jeruk manis (Citrus sinensis) yaitu limonene dan linalool dengan enzim tirosinase.

Pemodelan molekuler dengan docking senyawasenyawa kandungan utama ekstrak air buah jambu biji (Psidium guajava) yaitu 2,6-dihidroksi-3,5-dimetil-4O- $\beta$-D-glukopiranosilbenzofenon, dan 3-hidroksi-2butanon, sedangkan senyawa-senyawa kandungan ekstrak air buah jeruk manis (Citrus sinensis) yaitu limonene dan linalool di sisi aktif enzim tirosinase dilakukan melalui program Molegro Virtual Docker. Hasil pemodelan molekul (docking) berupa Dockscore dihitung dari konformasi stabil yang menunjukkan 
afinitas ikatan dari inhibitor enzim tirosinase yang terkompleks dengan ligan (senyawa-senyawa pada ekstrak air Psidium guajava dan Citrus sinensis). Semua senyawa pada dataset itu dimasukkan ke dalam sisi aktif pada enzim tirosinase dengan menggunakan protokol yang sama. Enzim tirosinase terdiri dari 2 protein dan yang digunakan adalah protein A karena di dalamnya terdapat native ligan yang bisa diekstraksi untuk mendapatkan active site. Enzim tirosinase adalah sebuah monomer terdiri dari sebuah lipatan $\alpha / \beta$. Lembaran besar $\beta$ dari tumpukan monomer satu sama lain untuk membentuk antarmuka dimer (warna merah), lipatan $\alpha$ (warna biru). Dimer ini berisi dua sisi aktif dimana satu di masing-masing monomer. Hal ini terlihat pada Gambar 4 enzim tirosinase dengan kandungan utama ekstrak air buah jambu biji (Psidium guajava) yaitu 2,6-dihidroksi-3,5-dimetil-4-O- $\beta$-Dglukopiranosilbenzofenon, dan 3-hidroksi-2-butanon, sedangkan ekstrak air buah jeruk manis (Citrus sinensis) yaitu limonene dan linalool (Gambar 4).

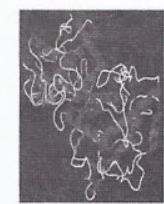

(a)

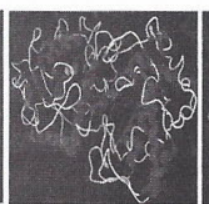

(b)

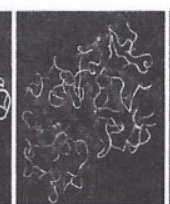

(c)

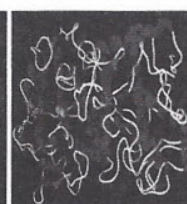

(d)

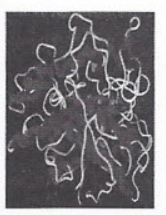

(e)
Gambar 4. Bentuk pita asam - asam amino dari enzim tirosinase yang berikatan dengan senyawa kandungan utama ekstrak air buah jambu biji (Psidium guajava) dan ekstrak air buah jeruk manis (Citrus sinensis). (a) 2,6-dihidroksi-3,5-dimetil-4-O- $\beta$-D-glukopiranosilbenzofenon, (b) 3-hidroksi-2-butanon, (c) vitamin C, (d) limonen, (e) linalool (warna biru lipatan $\beta$ dan merah lipatan $\alpha$ dari asam amino kuartener, warna hijau ligan senyawa uji dari ekstrak).

Sisi aktif enzim tirosinase pada senyawa kandungan utama ekstrak air buah jambu biji (Psidium guajava) 2,6-dihidroksi-3,5-dimetil-4-O- $\beta$-Dglukopiranosilbenzofenon terikat dengan 5 asam amino tirosinase antara lain Gly 200, Pro 201, Gly 196, Phe 197, dan Asn 205 sedangkan 3-hidroksi-2-butanon mengikat asam-asam amino Gly 200, Phe 197, dan Asn 205. Sisi aktif enzim tirosinase pada senyawa kandungan utama ekstrak air buah jeruk (Citrus sinensis) limonen dengan 3 asam amino tirosinase antara lain Gly 200, Phe197, Asn 205 sedangkan linalool mengikat asam-asam amino yang sama yaitu Gly 200, Phe197, Asn 205. Hal ini terlihat pada Gambar 5 dan Tabel 1 yaitu terbentuknya ikatan hidrogen antara enzim tirosinase dengan kandungan utama ekstrak air buah jambu biji (Psidium guajava) yaitu 2,6-dihidroksi-
3,5-dimetil-4-O- $\beta$-D-glukopiranosilbenzofenon, dan 3hidroksi-2-butanon, sedangkan ekstrak air buah jeruk manis (Citrus sinensis) yaitu limonene dan linalool. Semakin banyak asam amino yang terikat terutama dalam ikatan hidrogen maka ikatan semakin kuat dan energi scorenya semakin rendah/stabil (Gambar 5).

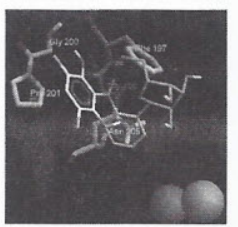

(a)

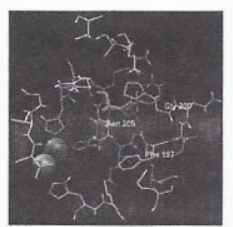

(b)

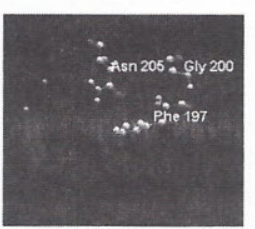

(c)

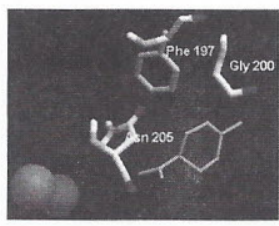

(d)

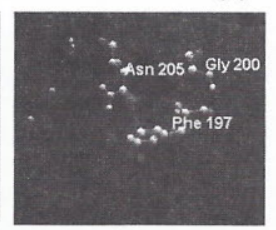

(e)
Gambar 5. Interaksi ikatan hidrogen dari enzim tirosinase yang berikatan dengan senyawa kandungan utama ekstrak air buah jambu biji (Psidium guajava) dan ekstrak air buah jeruk manis (Citrus sinensis). (a) 2,6-dihidroksi-3,5-dimetil-4-O- $\beta$-D-glukopiranosilbenzofenon, (b) 3-hidroksi-2-butanon, (c) vitamin C, (d) limonen, (e) linalool

Tabel 1. Interaksi ikatan hidrogen antara Ligan (senyawa kandungan utama ekstrak air buah jambu biji (Psidium guajava) dan ekstrak air buah jeruk manis (Citrus sinensis)) dengan Reseptor enzim tirosinase.

\begin{tabular}{cccccc}
\hline Nama Senyawa/Ligan & $\begin{array}{c}\text { Gly } \\
200\end{array}$ & Phe197 & $\begin{array}{c}\text { Asn } \\
205\end{array}$ & Gly 196 & $\begin{array}{c}\text { Pro } \\
201\end{array}$ \\
\hline $\begin{array}{c}\text { 2,6-dihidroksi-3,5-dimetil-4-O- } \\
\text { beta-Dglukopiranosilbenzofenon }\end{array}$ & + & + & + & + & + \\
\hline 3-hidroksi-2-butanon & + & + & + & - & - \\
\hline limonene & + & + & + & - & - \\
\hline linalool & + & + & + & - & - \\
\hline Vitamin C & + & + & + & - & - \\
\hline
\end{tabular}

Dari Gambar 5 menunjukkan bahwa sebagian besar residu asam amino pada sisi aktif hidrofobik terikat kuat dengan senyawa-senyawa kandungan utama ekstrak air buah jambu biji (Psidium guajava) yaitu 2,6-dihidroksi-3,5-dimetil-4-O- $\beta$-Dglukopiranosilbenzofenon, dan 3-hidroksi-2-butanon, dibandingkan ekstrak air buah jeruk manis (Citrus sinensis) yaitu limonene dan linalool yang terlihat. Gambar 6, 7, dan 8 menunjukkan keselarasan interaksi baik itu ikatan hidrofobik, elektrostatik dan pose organize pada senyawa kandungan utama ekstrak air buah jambu biji (Psidium guajava) lebih baik karena ligan uji bisa masuk active site daripada ekstrak air buah jeruk manis (Citrus sinensis). 


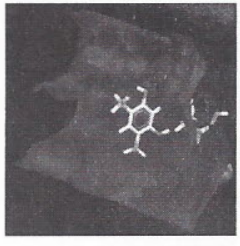

(a)

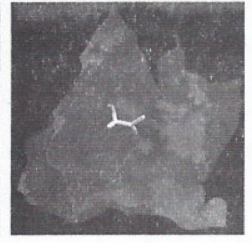

(b)

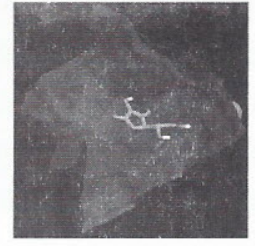

(c)

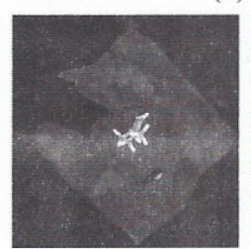

(d)

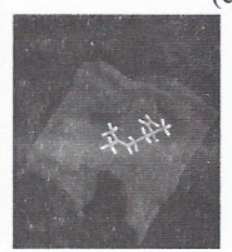

(e)
Gambar 6. Interaksi ikatan hidrofob antara enzim tirosinase yang berikatan dengan kandungan utama ekstrak air buah jambu biji (Psidium guajava) dan ekstrak air buah jeruk manis (Citrus sinensis). (a) 2,6dihidroksi-3,5-dimetil-4-O- $\beta$-D-glukopiranosilbenzofenon, (b) 3-hidroksi-2-butanon, (c) vitamin C, (d) limonen, (e) linalool

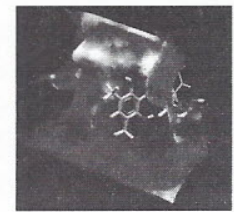

(a)

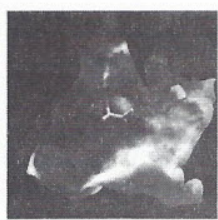

(b)

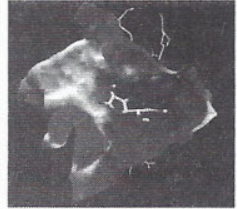

(c)

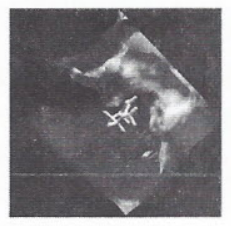

(d)

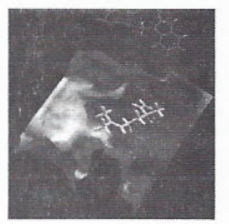

(e)
Gambar 7. Interaksi ikatan elektrostatik antara enzim tirosinase yang berikatan dengan senyawa kandungan utama ekstrak air buah jambu biji (Psidium guajava) dan ekstrak air buah jeruk manis (Citrus sinensis). (a) 2,6dihidroksi-3,5-dimetil-4-O- $\beta$-D-glukopiranosilbenzofenon, (b) 3-hidroksi-2-butanon, (c) vitamin C, (d) limonen, (e) linalool

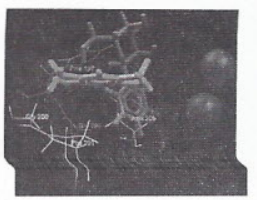

(a)

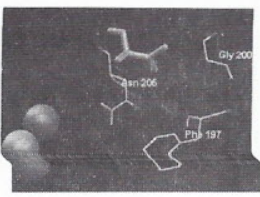

(b)

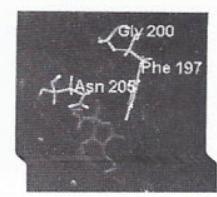

(c)

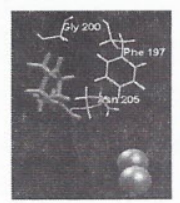

(d)

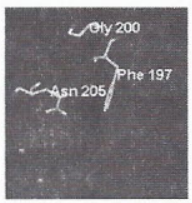

(e)
Gambar 8. Interaksi ikatan pada posisi yang terorganisasi ( pose organized) antara enzim tirosinase yang berikatan dengan senyawa kandungan utama ekstrak air buah jambu biji ( Psidium guajava) dan ekstrak air buah jeruk manis (Citrus sinensis ). (a) 2,6-dihidroksi-3,5dimetil-4-O-B-D-glukopiranosilbenzofenon, (b) 3-hid roksi-2-butanon, (c) vitamin C, (d) limonen, (e) linalool.
Sebagian besar kandungan utama ekstrak air buah jambu biji (Psidium guajava) yaitu 2,6-dihidroksi3,5-dimetil-4-O- $\beta$-D-glukopiranosilbenzofenon, dan 3hidroksi-2-butanon, sedangkan ekstrak air buah jeruk manis (Citrus sinensis) yaitu limonene dan linalool dan juga protein adalah polar dan nonpolar sehingga memanfaatkan sisi ikatan hidrogen dan hidrofobik rantai pada sisi aktif untuk ikatan. Kandungan utama ekstrak air buah jambu biji (Psidium guajava) yaitu 2,6dihidroksi-3,5-dimetil-4-O- $\beta$-D-glukopiranosilbenzofenon, dan 3-hidroksi-2-butanon, sedangkan ekstrak air buah jeruk manis (Citrus sinensis) yaitu limonene dan linalool mengikat dalam cara yang mirip dengan Kojic Acid dan Vitamin C sendiri sebagai senyawa yang sudah terbukti sebagai inhibitor enzim tirosinase dalam menempati cavity 3 pada bagian cincin aromatis ataupun rantai alifatisnya dan gugus karbonil ke arah pintu masuk rongga untuk membentuk ikatan hidrofobik $^{(19,24,25,30,31)}$. Cincin aromatis bersifat aktif dan lipofilik yang berhubungan dengan ikatan obat-reseptor sehingga kandungan utama ekstrak air buah jambu biji (Psidium guajava) yaitu 2,6-dihidroksi-3,5-dimetil-4O- $\beta$-D-glukopiranosilbenzofenon dapat mengikat ke sisi aktif enzim tirosinase lebih baik dibanding senyawa kandungan utama ekstrak air buah jeruk manis (Citrus sinensis) yaitu limonene dan linalool meskipun menempati inti dan sisi yang sama pada active site enzim tirosinase yang ditunjukkan dengan nilai afinitas ikatan dalam bentuk MolDock Score dan Rerank Scorenya. Nilai MoldockScore senyawa kandungan ekstrak air Psidium guajava nilainya lebih rendah dibanding senyawa kandungan ekstrak air Citrus sinensis yang menunjukkan ikatan ligan-reseptor antara senyawa pada ekstrak air Psidium guajava lebih stabil dibanding senyawa pada ekstrak Citrus sinensis (Tabel 2). Korelasi antara skor docking dan aktivitas hambatan ditunjukkan dengan nilai Dock Score, Rerank Score serta parameter fisikokimia senyawa pada ekstrak air buah jambu biji (Psidium guajava) yaitu 2,6-dihidroksi3,5-dimetil-4-O- $\beta$-D-glukopiranosilbenzofenon, dan 3hidroksi-2-butanon, sedangkan senyawa pada ekstrak air buah jeruk manis (Citrus sinensis) yaitu limonene dan linalool terlihat pada Tabel 2 dan 3.

Tabel 2. Parameter docking Ligan (senyawa pada ekstrak air ( Psidium guajava) ekstrak air buah jeruk manis ( Citrus sinensis ) pada sisi aktif enzim tirosinase.

\begin{tabular}{lcccc}
\hline \multicolumn{1}{c}{ Nama Senyawa /Ligan } & $\begin{array}{c}\text { MolDock } \\
\text { Score }\end{array}$ & $\begin{array}{c}\text { Rerank } \\
\text { Score }\end{array}$ & RMSD & HBond \\
\hline $\begin{array}{l}\text { 2,6-dihidroksi-3,5-dimetil-4-O- } \\
\text { B-D-glukopiranosilbenzofenon }\end{array}$ & $-107,802$ & $-82,2108$ & 7,49565 & $-5,03339$ \\
\hline 3-hidroksi-2-butanon & $-52,9507$ & -42.7666 & 20,1331 & $-5,31303$ \\
\hline Limonene & $-65,1346$ & $-55,2011$ & 20,8624 & 0 \\
\hline Linalool & $-76,9593$ & $-62,5321$ & 9,11606 & $-3,90414$ \\
\hline Vitamin C & $-87,9803$ & $-69,9446$ & 6,94160 & $-8,77158$ \\
\hline
\end{tabular}


Tabel 3. Parameter fisikokimia Ligan (senyawa kandungan utama ekstrak air buah jambu biji (Psidium guajava) dan ekstrak air buah jeruk manis (Citrus sinensis).

\begin{tabular}{lcccc}
\hline \multicolumn{1}{c}{ Nama Senyawa /Ligan } & LogP & ClogP & MR & CMR \\
\hline $\begin{array}{l}\text { 2,6-dihidroksi-3,5-dimetil-4-O- } \beta \text {-D- } \\
\text { glukopiranosilbenzofenon }\end{array}$ & 0,82 & 1,90548 & 106,34 & 10,304 \\
\hline 3-hidroksi-2-butanon & $-0,67$ & $-0,2044$ & 22,78 & 2,2214 \\
\hline Limonene & 3,01 & 4,352 & 46,86 & 4,5878 \\
\hline Linalool & 2,55 & 2,749 & 50,72 & 4,9177 \\
\hline Vitamin C & $-3,36$ & $-1,7599$ & 36,61 & 3,6346 \\
\hline \multicolumn{4}{c}{ Keterangan: $\begin{array}{l}\text { LogP, ClogP, MR, and CMR value calculated by } \\
\text { ChemBioDraw Ultra 11.0 Program }\end{array}$} \\
\end{tabular}

Berdasarkan nilai MolDock Score, Rerank Score, dan parameter fisikokimia menunjukkan bahwa senyawa kandungan utama ekstrak air buah jambu biji (Psidium guajava) yaitu 2,6-dihidroksi-3,5-dimetil-4O- $\beta$-D-glukopiranosilbenzofenon, dan 3-hidroksi-2butanon memberikan energi yang lebih rendah sehingga stabil dalam pengikatan dan keselarasan ikatan dalam active site. Hasil docking tersebut sesuai dengan nilai parameter fisikokimianya dimana nilai MR (Molar Refraction) yang merupakan parameter sterik yang berhubungan dengan keserasian ikatan ligan dan reseptor senyawa kandungan utama ekstrak air buah jambu biji (Psidium guajava) yaitu 2,6-dihidroksi-3,5dimetil-4-O- $\beta$-D-glukopiranosilbenzofenon lebih besar dibanding senyawa kandungan utama ekstrak air buah jeruk manis (Citrus sinensis) yaitu limonene dan linalool sehingga mempengaruhi ikatan ligan dan reseptor dalam active site yang pada akhirnya mempengaruhi aktivitasnya (Tabel 3) ${ }^{(19,24,25,30,31)}$. Aplikasi penting dari program docking Molegro Virtual Docker dalam rancangan obat adalah untuk memprediksi aktivitas hambatan kompetitif agen pemutih kulit pada enzim tirosinase dalam menentukan konformasi pengikatan inhibitor dengan memanfaatkan skor ikatan dimana pada penelitian ini menunjukkan bahwa senyawa kandungan utama ekstrak air buah jambu biji (Psidium guajava) yaitu 2,6-dihidroksi-3,5dimetil-4-O- $\beta$-D-glukopiranosilbenzofenon, dan 3hidroksi-2-butanon yang disubstitusi gugus aromatis dan gugus karbonil memberikan hasil ikatan yang lebih baik dibandingkan kandungan utama ekstrak air buah jeruk manis (Citrus sinensis) yaitu limonene dan linalool yang terlihat dari nilai Moldock score dan Rerank score. Hasil ini sesuai jika dilihat secara 3D ikatan senyawa kandungan utama ekstrak air buah jambu biji (Psidium guajava) yaitu 2,6-dihidroksi-3,5dimetil-4-O- $\beta$-D-glukopiranosilbenzofenon, dan 3hidroksi-2-butanon pada reseptornya memberikan interaksi yang lebih baik dibandingkan kandungan utama ekstrak air buah jeruk manis (Citrus sinensis) yaitu limonene dan linalool baik ikatan hidrogen, hidrofobik dan elektrostatiknya. Hasil pemodelan molekuler ini linier dengan uji in vitro terhadap enzim tirosinase dilihat dari harga Inhibitor Concentration $\left(\mathrm{IC}_{50}\right)$ ekstrak air buah jambu biji (Psidium guajava) memberikan nilai aktivitas yang lebih tinggi dibandingkan dengan ekstrak air buah jeruk manis (Citrus sinensis) yang dapat dilihat pada Tabel $4^{(1,3,26)}$.

Tabel 4. Hasil Uji Aktivitas senyawa ekstrak air buah jambu biji (Psidium guajava) dan ekstrak air buah jeruk manis (Citrus sinensis) terhadap enzim tirosinase dengan menggunakan metode Spektrofotometri (in vitro).

\begin{tabular}{cc}
\hline Nama Senyawa /Ligan & $\boldsymbol{I C}_{50}$ \\
\hline Ekstrak air buah jambu biji (Psidium guajava) & $0,26 \mathrm{mM}$ \\
\hline Ekstrak air buah jeruk manis (Citrus sinensis) & $31,07 \mathrm{mM}$ \\
\hline Vitamin C & $0,28 \mathrm{mM}$ \\
\hline
\end{tabular}

hasil percobaan pemodelan molekuler (docking) kandungan utama ekstrak air buah jambu biji (Psidium guajava) sebagai pemutih kulit dengan Molegro Virtual Docker maka dapat disimpulkan bahwa interaksi senyawa pada ekstrak air buah jambu biji (Psidium guajava) terhadap enzim tirosinase lebih harmonis dan stabil daripada vitamin $\mathrm{C}$ dan kandungan utama ekstrak air jeruk manis (Citrus sinensis) yang didukung dengan gambar 3D, nilai MolDock Score, Rerank Score, dan parameter fisikokimianya.

\section{KESIMPULAN}

Pada penelitian ini didapatkan hasil senyawa kandungan utama ekstrak air buah Psidium guajava memiliki ikatan yang lebih baik sebagai inhibitor enzim tirosinase daripada Citrus sinensis dan vitamin C yang dapat dilihat dari Moldock score dan Rerank score berturut turut $-107,802$ dan $-52,9507$ yang artinya memiliki energi yang lebih rendah sehingga lebih stabil dalam pengikatannya. Hasil sama ditunjukkan dari uji in vitro pada ekstrak air buah jambu biji (Psidium guajava) dengan $\mathrm{IC}_{50} 0,26 \mathrm{mM}$ sedangkan ekstrak air jeruk manis (Citrus sinensis) $\mathrm{IC}_{50} 31,07 \mathrm{mM}$. Hal ini juga didukung data ikatan hidrogen pada kandungan utama ekstrak air buah jambu biji (Psidium guajava) 2,6-dihidroksi-3,5-dimetil-4-O- $\beta$-D-glukopiranosilbenzofenon dengan 5 asam amino tirosinase antara lain Gly 200, Pro 201, Gly 196, Phe 197, dan Asn 205 sedangkan limonene, linalol mengikat 3 asam amino 
Gly 200, Phe 197, dan Asn 205. Dengan demikian dapat disimpulkan bahwa interaksi senyawa pada ekstrak air buah jambu biji (Psidium guajava) terhadap enzim tirosinase lebih harmonis dan stabil daripada vitamin C maupun senyawa kandungan utama ekstrak air jeruk manis (Citrus sinensis).

\section{UCAPAN TERIMA KASIH}

Penulis banyak mengucapkan terima kasih kepada Prof. Dr. Siswandono.,MS.,Apt and Hadi Poerwono.,MSc,Apt.,Ph.D atas bantuan dari program software docking yang digunakan dalam penelitian ini.

\section{DAFTAR PUSTAKA}

1. A. Anggraini, Skripsi: Pengaruh Ekstrak Buah Jeruk (Citrus sinensis) terhadap Aktivitas Tirosinase (EC 1.14.18.1). Fakultas Farmasi, Universitas Jember, Jember (2008) (unpublish)

2. A.R. Proteggente, A. Saija,A. De Pasquale \& C.A. Rice-evans. The Compositional Characterisation and Antioxidant Activity of Fresh Juices from Sicilian Sweet Orange (Citrus sinensis, L. Osbeck) Varieties, Free Radical Research, 37. 2003. pp. 681-687.

3. A.R. Puspaningtyas. Skripsi: Pengaruh Asam 3,4Dihidroksisinamat dan Asam 4-Hidroksi-3Metoksisinamat Terhadap Aktivitas Tirosinase. Fakultas Farmasi, Universitas Airlangga, Surabaya (2003)(unpublish)

4. Departemen Kesehatan RI. Formularium Kosmetika Indonesia, Jakarta.1995, pp 20-70

5. D.E. Okwu. Phytochemicals and vitamin content of indigenous spices of South Eastern Nigeria. Journal of Sustainable Agric and Environment, 6, 30-37(2004)

6. D.E. Okwu. Phytochemicals, vitamins, and mineral content of two Nigerian medicinal plants. International Journal of Molecular Medicine and Advance Sciences, 1,375-381 (2005)

7. F.I. Kanaze, A. Termentzi, C. Gabrieli, I. Niopas, M. Georgarakis \& E. Kokkalou,. The phytochemical analysis and antioxidant activity assessment of orange peel (Citrus sinensis) cultivated in Greece-Crete indicates a new commercial source of hesperidin, Biomedical Chromatography, 23 pp.239-249 (2008)

8. F.S. Munoz, R. Penafiel and J.D. Galindo. An
Electrometric Method for The Determination of Tyrosinase Activity. Biochem, J. 229 (1985).

9. H. Kumamoto, Y. Matsubara, Y. lizuka, K. Okamoto \& K. Yokoi. Structure and Hypotensive Effect of Flavonoid Glycosides in Orange (Citrus sinensis OSBECK) Peelings, Agricultural and Biological Chemistry, 50, 1986, pp. 781-783

10. J.C. Paniandy, J. Chane-Ming, J.C. Pieribattesti. Chemical compotition of essential oil and headspace solid-phase microextraction of guava fruit (Psidium guajava.L). Journal of Essential Oil Research, 12,2,153-158(2000)

11. J.V. Kamath, N. Rahul, C.K. Ashok, and S.M. Lakshmi. Psidium guajava L. A review. Int. J. Green Pharm, 2: 9-12(2008)

12. K. Ashok kumar et al. Antimicrobial Activity and Phytochemical Analysis of Citrus Fruit Peels Utilization of Fruit Waste. International Journal of Engineering Science and Technology (IJEST) Vol.3, No.6, June, 5420. (2011)

13. L. Stryer. Biochemistry, 4th ed. W. H Freeman and Company, California.1997, pp 24-70

14. M.J. Jordan, C.A. Margaria, P.E. Shaw, K.L. Goodner. Volatile components and aroma active compounds in aqueous essence and fresh pink guava fruit puree (Psidium guajava.L) by GC-MS and multidimentional GC-GC-O. J.Agric. Food Chem.Feb 26;51(5):1421-6(2003)

15. M.M. Ahmad, Z. Salim-ur-Rehman, F.M. Iqbal, Anjum and J.I. Sultan. Genetic variability to essential oil composition in four citrus fruit species. Pak.J. Bot., 38(2): pp.319-324 (2006)

16. M.O. Rodriquez and W.H.A. Flurkey. Biochemistry Project to Study Mushroom TJ. W. H Freeman and Company, California.1992, pp 267270

17. M. Schurink. Peptides as inhibitors of lipoxygenase and tyrosinase. http://www.library. wur.nl/wda/dissertations/dis4329.pdf, diakses 15 Mei 2008

18. Nadendla, R. Rama. Molecular Modeling: A Powerful Tool for Drug and Molecular Docking. India: General article. http: http://www.pharmainfo.net/nadendla/publication s/molecular-modeling-powerful-tool-drugdesign, diakses tanggal 29 september 2012. 
19. N. Kamkaen, N. Mulsri and C. Treesak. Screening of Some Tropical Vegetables for Anti-tyrosinase Activity. Thai Pharm Health Sci. J. 2: 15-19 (2007).

20. P. Mittal, V. Gupta, G. Kaur, A.K. Garg, and A. Sign. Phytochemistry And Pharmacological Activities Of Psidium Guajava: A Review, India : Akal College of Pharmacy, UCER, Baba Farid University of Health Sciences and Technical Education, IJPSR, 1 (9): 9-19(2010).

21. R.F. Boyer, 1993. Modern Experimental Biochemistry $2^{\text {nd }}$ ed. The Benjamin Cumming Publishing Co., California.

22. R.G. Brown, and T. Burns, Lecture Notes on Dermatology. Disadur Zakaria. Lecture Notes on Dermatologi. PenerbitErlangga, Jakarta. 2002, pp 695-699

23. R.J. Fessenden, dan J.S. Fessenden. Fundamentals of Organic Chemistry. Alih bahasa Maun, Sukmariah dkk. Dasar-dasar Kimia Organik. Jakarta: BinarupaAksara, 1997, p.2-79

24. R. Thomsen, and M.H. Christensen. MolDock: A new technique for high-accuracy docking. $J$ Med Chem, 49:3315-3321.(2006)

25. S.Aisyah. Skripsi: Pengaruh Ekstrak Buah Jambu (Psidium guajava) terhadap Aktivitas Tirosinase (EC 1.14.18.1). Fakultas Farmasi, Universitas Jember, Jember (2009) (unpublish)

26. S. Briganti, E. Camera, and M. Picardo. Chemistry and Instrumental Approaches to Treat Hyperpigmentation. Pigment Cell. Res. 16 : 101$110(2003)$
27. S.C. PANKAJA, Phytochemical Analysis Of Citrus Sinensis Peel, International Journal of Pharma and Bio Sciences, Jan; 4(1): (B) 339-343 (2013)

28. S. Martoharsono. Biokimia Jilid 1. Gadjah Mada Universiy Press, Yogyakarta 1985, pp 1-50

29. S. Naeem, P. Hylands, and D. Barlow. Docking Studies of Chlorogenic Acid against Aldose Redutcase by using Molegro Virtual Docker Software, Journal of Applied Pharmaceutical Science Vol. 3 (01), pp.013-020(2013)

30. Siswandono dan B. Soekardjo. Kimia Medisinal. Jilid 1 Edisi ke-2. Surabaya : Airlangga University Press. 2000, pp.121-132,183

31. S. Yusof, Guavas. Universiti Putra Malaysia, Selangor, Malaysia, Elsevier Science Ltd, 2003, pp.2985-2991.

32. T. Mitsui. New Cosmetic Science. Elsevier Science,Amsterdam.1997,pp 148-150

33. W. Zhu and J. Gao. The Use of Botanical Extracts as Topical Skin-Lightening Agents for the Improvement of Skin Pigmentation Disorders. http://www.nature.com/jidsp/journal/v13/n1/pdf/ jidsymp20088a.pdf. Diakses 11 Mei 2008.

34. Y. Qiao, B.J. Xie, Y. Zhang, G. Fan, L.X. Yao, and S.Y. Pan. Characterization of Aroma Active Compounds in Fruit Juice and Peel Oil of Jinchen Sweet Orange Fruit (Citrus sinensis (L.) Osbeck) by GC-MS and GC-O, China : College of Food Science and Technologhy, Huazhong Agricultural University, Molecules, 13:1333-1344 (2008) calendulacea Less stem extract, Phytomedicine 15,959-970. 